\title{
Two Hippolytid Shrimps (Crustacea: Decapoda: Caridea) from the Deepwater of the East Sea, Korea
}

\author{
Jung Nyun Kim ${ }^{1, *}$, Jung Hwa Choi ${ }^{1}$, Byeong Gyu Hong ${ }^{2}$, \\ Kang Seok Hwang ${ }^{2}$ and Young Yull Chun ${ }^{2}$ \\ 'Fisheries Resources Research Team, National Fisheries Research and \\ Development Institute, Busan 619-705, Korea \\ ${ }^{2}$ Deep-sea Research Center, East Sea Fisheries Research Institute, \\ National Fisheries Research and Development Institute, Pohang 791-110, Korea
}

\begin{abstract}
Two hippolytid shrimps, Spirontocaris spinus (Sowerby, 1805) and Lebbeus unalaskensis (Rathbun, 1902) are described on the basis of material collected from the deepwater of the East Sea, Korea at 310-810 m. The former has been incorrectly known as Spirontocaris arcuata Rathbun, 1902 in Korea and the latter is a new member of the Korean fauna. Morphological and distributional accounts of these species are presented with illustrations.
\end{abstract}

Key words: Spirontocaris spinus, Lebbeus unalaskensis, Caridea, Decapoda, Deepwater, East Sea, Korea, new record

\section{INTRODUCTION}

The family Hippolytidae contains 272 species and five subspecies of 40 genera in the world (Chace, 1997; Bruce, 1997; Crosnier, 2000; Sokolov, 2002). Of 25 hippolytid shrimps have been known from Korean waters, six species reported from the deepwater of Korean coast of the East Sea (Kim, 1977; Cha et al., 2001; Kim and Choi, 2006). During the sampling expeditions of the National Fisheries Research and Development Institute (NFRDI), two interesting hippolytid shrimp species were collected from the deepwater of the East Sea. After the close examination, they were identified with Spirontocaris spinus (Sowerby, 1805) and Lebbeus unalaskensis (Rathbun, 1902). Spirontocaris spinus has been incorrectly known as Spirontocaris arcuata Rathbun, 1902 in Korea by previous authors (Kim and Park, 1972; Kim, 1976, 1977; Kim and Moon, 1994; Kim and Kim, 1997; Cha et al., 2001). Lebbeus unalaskensis is a new member of the Korean fauna. Morphological and distributional accounts of these species are briefly discussed. Specimens examined in this study are deposited in the NFRDI. Postorbital carapace length (CL) is used as an indication of the standard size of the specimens.

\footnotetext{
*To whom correspondence should be addressed

Tel: 82-51-720-2287, Fax: 82-51-720-2277

E-mail: crangonk@momaf.go.kr
}

\section{SYSTEMATIC ACCOUNTS}

Family Hippolytidae Bate, 1888

${ }^{1 *}$ Spirontocaris spinus (Sowerby, 1805) (Fig. 1)

\section{Restricted synonymy}

Cancer spinus Sowerby, 1805, p. 47, pl. 23.

Spirontocaris spinus: Rathbun, 1904, p. 9, 57, 63; Brashnikov, 1907 , p. 138, fig. 14c; Holthuis, 1947, pp. 8, 37;

Hayashi, 1977 , p. 177 , figs. 8,9 (see full synonymy); 1993b, p. 164, figs. 243g, 244i; Komai, 1991, p. 71; 1994, p. 82; Komai et al., 1992, p. 194.

Spirontcaris arcuata: Kim and Park, 1972, p. 199, pl. 3, fig. 1; Kim, 1976 , p. 143 ; 1977 , p. 255 , pls. 25 , 50, fig. 46 , text-fig. 104; Kim and Moon, 1994, p. 263; Kim and Kim, 1997, p. 214; Cha et al., 2001, p. 118, unnumbered fig. (not Spirontocaris arcuata Rathbun, 1902)

Type locality. Among oysters on the Scottish coast (Sowerby, 1805).

Material examined. 10 우 우 (cl 12.0-19.0 mm), 6 ovig. 우 우 (cl 13.8-116.5 mm), East Sea, off Samcheok, $37^{\circ} 26.6^{\prime} \mathrm{N}$ $129^{\circ} 28.4^{\prime} \mathrm{E} \rightarrow 37^{\circ} 24.1^{\prime} \mathrm{N} 129^{\circ} 32.9^{\prime} \mathrm{E}, 19$ May 2005 , by otter trawl at $310 \mathrm{~m}$ in depth, NFRDI; 9 우 우 (cl 9.0-16.6 mm), 3 ovig. 우우 (cl 14.8-16.4 mm), East Sea, off Samcheok, $37^{\circ}$ $27.9^{\prime} \mathrm{N} 129^{\circ} 36.1^{\prime} \mathrm{E} \rightarrow 37^{\circ} 24.8^{\prime} \mathrm{N} 129^{\circ} 39.7^{\prime} \mathrm{E}, 20$ May 2005 , by otter trawl at $505 \mathrm{~m}$ in depth, NFRDI.

Description. Body robust; integument moderately thin. Rostrum (Fig. 1A) deep, straight, slightly reaching beyond

\footnotetext{
$1 *$ 톱동큰꼬마새우
} 


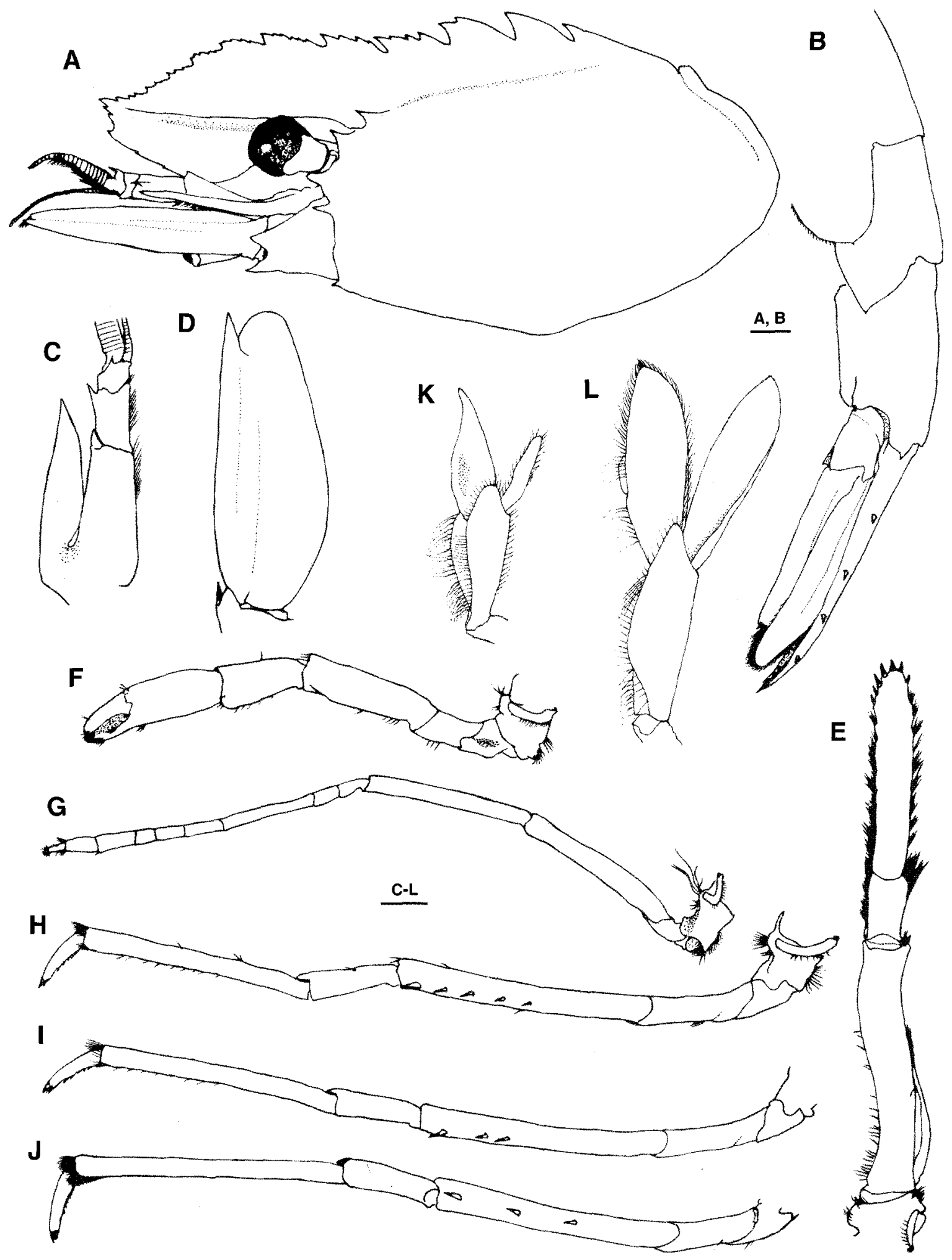

Fig. 1. Spirontocaris spinus (Sowerby, 1805). Female (CL $17.7 \mathrm{~mm}$, NFRDI) from the East Sea. Dissected appendages all left side. A, carapace, lateral; B, fourth to sixth abdominal somites, telson and uropods, lateral; $C$, antennule, dorsal, distal parts of flagella omitted; D, scaphocerite, dorsal; $E$, third maxilliped, ventral; $F$, first pereopod, lateral; $G$, second pereopod, lateral; $H$, third pereopod, lateral; I, fourth pereopod, lateral; J, fifth pereopod, lateral; K, first pleopod, ventral, marginal setae of exopod omitted; $L$, second pleopod, ventral, marginal setae of exopod omitted. Scale bars $=2 \mathrm{~mm}(A-L)$. 
distal margin of antennular peduncle, 0.71-0.83 times as long as carapace, with well-developed lateral carina; apex sharply pointed; dorsal margin with 7-10 main teeth and several secondary small teeth; ventral margin with 2-6 small teeth. Carapace (Fig. 1A) glabrous; middordsal carina with 4 or 5 large teeth, anterior first or first two teeth with 1-3 secondary small teeth in large specimens; two supraorbital spines well developed; antennal spine moderately large; suborbital lobe pointed, larger than antennal spine; pterygostomian spine small. Abdomen (Fig. 1B) smooth dorsally; pleura of first to third somites rounded, those of fourth to sixth somites pointed posteriorly. Telson (Fig. 1B) with basically 4 pairs of minute spines on dorsolateral margin, rarely 3 spines on one side; posterior margin with 3 pairs of small spines. Eye (Fig. 1A) moderately small, pyriform; cornea well-developed. Antennular peduncle (Fig. 1C) reaching anterior $2 / 3$ of scaphocerite of antenna; stylocerite moderately narrow, pointed distally, reaching or slightly beyond of second segment of antennular peduncle; first segment longer than second and third segments combined, with distinct ventral tooth; second segment longer than third segment, distolateral margin with small tooth; third segment with small tooth on dorsodistal margin. Antenna with scaphocerite (Fig. 1D) moderately robust, 0.68-0.76 times as long as carapace, 2.59-2.84 times as long as wide; distolateral spine slightly overreaching distal margin of blade; basicerite with 2 lateral processes, lower process sharply pointed. Third maxilliped (Fig. 1E) slightly falling short of or slightly overreaching distal margin of scaphocerite; antepenultimate segment slightly shorter than distal 2 segments combined; penultimate segment short, $1 / 3$ of ultimate segment; ultimate segment rounded distally, with many marginal spines; exopod and epipod present. First 3 pereopods (Fig. 1F-H) each with epipod. First pereopod (Fig. 1F) moderately robust, short, reaching midlength of scaphocerite. Second pereopod (Fig. 1G) slender, long, overreaching distal margin of scaphocerite by chela; carpus subdivided into 7 articles. Posterior 3 pereopods (Fig. 1H-J) slender and long; dactyli with 7-9 minute spines on ventral margin. Third pereopod (Fig. 1H) overreaching distal margin of scaphocerite by dactylus only or dactylus and distal $1 / 4$ of propodus; merus with 3-8 small spines. Fourth pereopod (Fig. 1I) overreaching distal margin of scaphocerite by dactylus only or distal $1 / 10$ of propodus; merus with 3-6 small spines. Fifth pereopod (Fig. 1J) overreaching distal margin of scaphocerite by distal half of dactylus; merus with 2-4 small spines. First pleopod (Fig. 1K) with endopod slender, rounded distally, reaching beyond half of exopod. Second pleopod (Fig. 1L) with endopod large, broad, reaching distal end of exo- pod, with appendix interna.

Coloration. Body dark red with greenish brown or light green spots, sometimes with red spots.

Distribution. Circumpolar. Atlantic Ocean from southward to the northern North Sea, East coast of America, Massachusetts Bay. Pacific Ocean from Bering Sea, Okhotsk Sea, East Sea (Japan Sea), and Pacific coast of Hokkaido, Japan; 5-1,380 m (Hayashi, 1977); 310-505 m in Korean waters.

Remarks. The present specimens are referable to S. spinus, which species was adequately revised by Hayashi (1977). The hippolytid shrimp having the laterally compressed rostrum with teeth on the upper and lower margins, two supraorbital teeth on the carapace, the posterior dorsal tooth on the carapace situated on the posterior third of the carapace, and the first three pereopods with an epipod has been known as Spirontocaris arcuata Rathbun, 1902 by Korean authors (Kim and Park, 1972; Kim, 1977; Cha et al., 2001). Spirontocaris spinus (Sowerby, 1805) also bears these characters but is distinguished from $S$. arcuata in having the relatively short stylocerite and relatively slender scaphocerite with the short distolateral spine. The stylocerite reaches the distal margin of the second segment of antennular peduncle in $S$. spinus while it overreaches the distal margin of the third segment in S. arcuata. The scaphocerite is 2.5-2.8 times as long as wide and the distolateral spine reaches slightly beyond the distal margin of blade in $S$. spinus while the scaphocerite is about 3.0 times and the distolateral spine distinctly overreaches the distal margin of blade in S. arcuata (see Hayashi, 1977). The Korean specimens including the present material have the short stylocerite (Fig. 1C) and the narrow scaphocerite with the short distolateral spine (Fig. 1D). They, therefore, should be referable $S$. spinus not to $S$. arcuata. Spinrontocaris spinus is only species belonging to that genus known in Korean waters. It shows a circumpolar distribution at depths of 9-1,380 m (Hayashi, 1977) and occurred in the East Sea at depths of 310-505 $\mathrm{m}$ in Korea.

\section{$i *$ Lebbeus unalaskensis (Rathbun, 1902) (Fig. 2) \\ Restricted synonymy}

Spirontocaris unalaskensis Rathbun, 1902, p. 895; 1904, p. 74, fig. 28; Miyake et al., 1962, p. 123.

Lebbeus unalaskensis: Holthuis, 1947, pp. 9, 39; Igarashi, 1969, p. 6, pl. 6, fig. 16, pl. 15, fig. 44; Hayashi, 1992, p. 134 (see full synonymy); 1993a, p. 9, figs. 236f, 237f, 238b, c; Komai et al., 1992, p. 193; Komai, 1994, p. 82.

Type locality. North of Unalaska Island, Bering Sea, $54^{\circ}$ $01^{\prime} 40^{\prime \prime} \mathrm{N} 166^{\circ} 48^{\prime} 45^{\prime \prime} \mathrm{E}, 566 \mathrm{~m}$ (Rathbun, 1902).

Material examined. 1 우 (cl $19.7 \mathrm{~mm}$ ), East Sea, off Sam-

1*알래스카가시배새우 (신칭) 


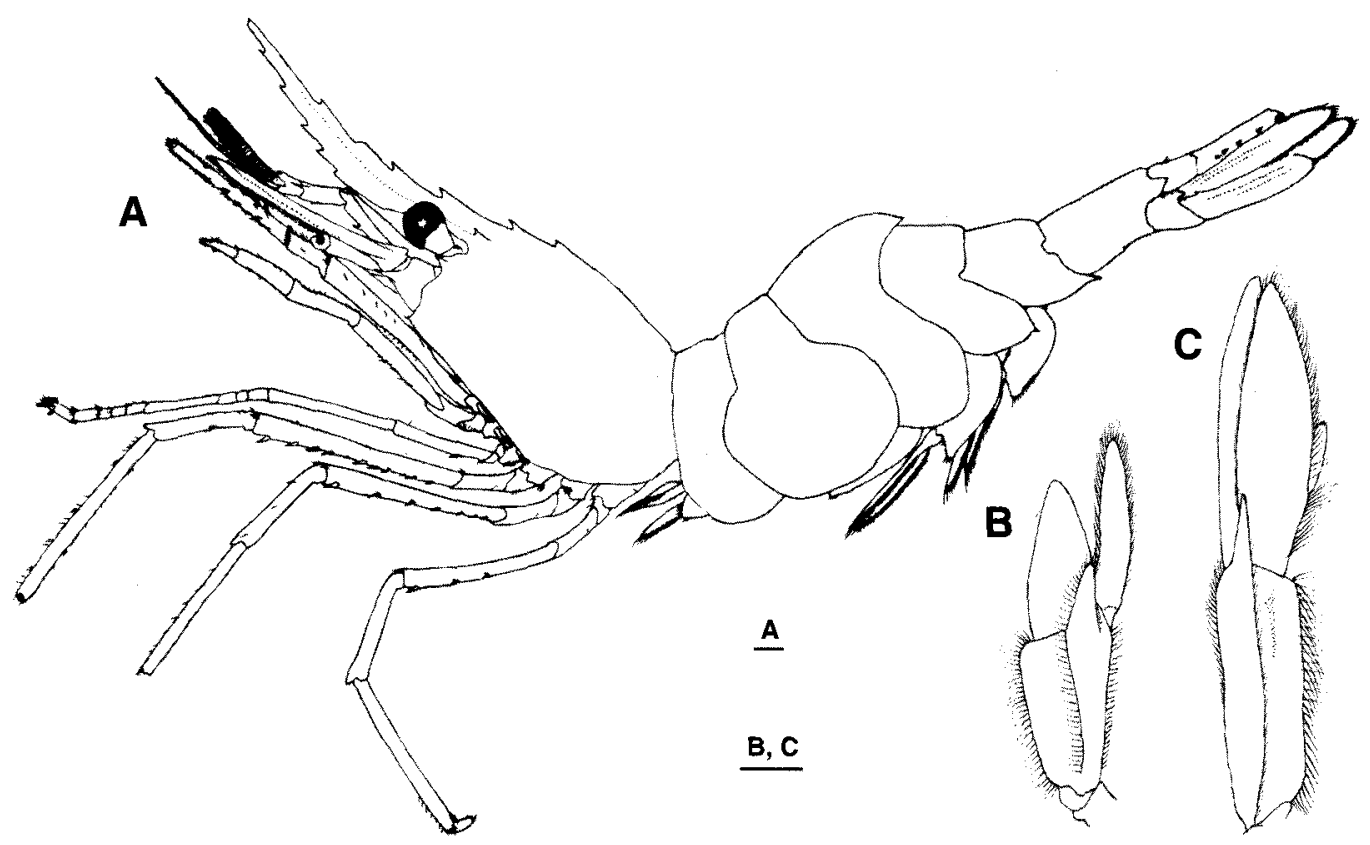

Fig. 2. Lebbeus unalaskensis (Rathbun, 1902). Female (CL $19.7 \mathrm{~mm}$, NFRDI) from the East Sea; $A$, entire animal, lateral, dactyli of third and fourth pereopods missing; B, left first pleopod, ventral, marginal setae of exopod omitted; C, right second pleopod, ventral, marginal setae of exopod omitted. Scale bars $=2 \mathrm{~mm}(A-C)$.

cheok, $37^{\circ} 27.3^{\prime} \mathrm{N} 129^{\circ} 46.3^{\prime} \mathrm{E} \rightarrow 37^{\circ} 28.4^{\prime} \mathrm{N} 129^{\circ} 45.6^{\prime} \mathrm{E}, 16$ Mar. 2006, by otter trawl at $810 \mathrm{~m}$ in depth, NFRDI .

Description. Body moderately slender; integument moderately thin. Rostrum (Fig. 2A) long, overreaching distal margin of scaphocerite, 1.33 times as long as carapace, ascending, with acute apex; lateral carina weak; dorsal margin with 6 teeth including 2 teeth on carapace; ventral margin with 6 teeth. Carapace (Fig. 2A) without distinct median carina; supraorbital spine small; antennal spine moderately strong; pterygostomian spine small. Abdomen (Fig. 2A) smooth dorsally; pleura of first 3 somites rounded, those of fourth and fifth somites each with small posteroventral tooth; sixth somite (Fig. 2A) 1.79 times as long as proximal width, posterior process with tooth posteriorly. Telson (Fig. 2 A) broken distally, remaining part with 5 pairs of dorsolateral spines. Eye (Fig. 2A) moderately large, pyriform; cornea well-developed. Antennular peduncle (Fig. 2A) long, reaching level of $3 / 4$ length of scaphocerite; each segment with marginal spine distally; antepenultimate segment with ventral spine. Scaphocerite (Fig. 2A) moderately slender, 0.90 times as long as carapace, 3.07 times as long as wide; distolateral spine falling distinctly short of distal margin of blade. Third maxilliped and first 2 pereopods with epipod. Pereopods (Fig. 2A) slender; first pereopod falling short of distal margin of scaphocerite; second pereopod overreaching distal margin of scaphocerite by chela and distal article of carpus, carpus subdivided into 8 articles; meri of posterior 3 pereopods with 9, 7, 3 small spines, respectively; dactylus of fifth pereopod biunguis. First pleopod (Fig. 2B) with endopod long, reaching beyond distal end of stout exopod. Endopod of second pleopod (Fig. 2C) subequal to exopod in length, with appendix interna.

Coloration. Boby pale red with dark red latitudinal long spots, distal half of telson red.

Distribution. Northern North Pacific from Bering Sea, Okhotsk Sea, East Sea (Japan Sea); 182-669 m (Hayashi, 1992), $810 \mathrm{~m}$ in Korean waters.

Remarks. Lebbeus unalaskensis (Rathbun, 1902) has been known to the north of Unalaska Island, Bering Sea, Okhotsk Sea, and Japanese coast of the East Sea in depths of 182$669 \mathrm{~m}$. Although the present material examined is only one female collected from off Samcheok at a depth of $800 \mathrm{~m}$, it agrees with the characters of $L$. unalaskensis revised by Hayashi (1992) especially in the long rostrum reaching beyond the scaphocerite, the posteriorly pointed pleuron of fourth abdominal somite, the first segment of antennualr peduncle with a single distal tooth on the dorsolateral margin, and the first two pereopods with an epipod. The carpus of second pereopod having seven articles is a diagnostic character of the genus Lebbeus (see Hayashi, 1992). The present specimen, however, has the carpus of second pereopod which is subdivided eight articles. It may be an unusual or variable character of the species. In Korean waters, two species of the genus Lebbeus, L. groenlandicus (Fabricius, 1775) and $L$. 
polaris (Sabine, 1882) are reported from the East Sea (Kim, 1977; Cha et al., 2001). The present species is easily distinguished from the two species by the long, ascending rostrum. In the two species, the rostrum is straight and falling short of or just reaches the distal margin of the scaphocerite.

\section{ACKNOWLEDGEMENTS}

We cordially thank Dr. Ken-Ichi Hayashi of the Shrimp and Prawn Research Laboratory, Shimonoseki, Japan for his critical reading of the manuscript. This work was funded by the National Fisheries Research and Development Institute (RP-2007-FR-039).

\section{REFERENCES}

Brashnikov, V., 1907. Materiali po fauni Russkikh vostochnikh morei, sovrannie shkhnoju "Storoz" vi 1899-1902 gg. [Materials on the fauna of Russian Eastern Sea collected by the schooner "Storoz" during the year 1899-1902]. Zapiski Imperatorskoi Akademii Nauki, po phiziki-matematichekomu otdilenileniju, 20: 1-185.

Bruce, A.J., 1997. A new genus of hippolytid shrimp (Crustacea: Decapoda: Hippolytidae) for Thor maldivensis Borradaile. Mem. Queensl. Mus., 42: 13-23.

Cha, H.K., J.U. Lee, C.S. Park, C.I. Baik, S.Y. Hong, J.H. Park, D.W. Lee, Y.M. Choi, K. Hwang, Z.G. Kim, K.H. Choi, H. Sohn, M.H. Sohn, D.H. Kim and J.H. Choi, 2001. Shrimps of the Korean Waters. National Fisheries Research and Development Institute, Pusan, pp. 1-188.

Chace, F.A., Jr., 1997. The caridean shrimps (Crustacea: Decapoda) of the Albatross Philippine Expedition, 1907 1910, Part 7: Families Atyidae, Eugonatonotidae, Rhynchocinetidae, Bathypalaemonellidae, Processidae, and $\mathrm{Hi}-$ ppolytidae. Smithson. Contrib. Zool., 587: 1-106.

Crosnier, A., 2000. A new genus and species of hippolytid shrimp (Decapoda, Caridea) from Wallis Island, Southwest Pacific. J. Crust. Biol., 20 (suppl.): 109-115.

Hayashi, K.-I., 1977, Studies on the hippolytid shrimps from Japan-VI. The genus Spirontocaris Bate. J. Shimonoseki Univ. Fish., 25(3): 155-186.

Hayashi, K.-I., 1992, Studies on the hippolytid shrimps from Japan-VIII. The genus Lebbeus White. J. Shimonoseki Univ. Fish., 40(3): 107-138.

Hayashi, K.-I., 1993a. Prawns, shrimps and lobsters from Japan (69). Family Hippolytidae-genus Lebbeus (3). Aquabiology 84, 15(1): 6-9. (in Japanese)

Hayashi, K.-I., 1993b. Prawns, shrimps and lobsters from Japan (71). Family Hippolytidae-genus Spirontocaris (2). Aquabiology 86, 15(3): 161-165. (in Japanese)

Holthuis, L.B., 1947. The Hippolytidae and Rhynchocinetidae collected by the Siboga and Snellius Expeditions with re- marks on other species. In The Decapoda of the Siboga Expedition, Part IX. Siboga-Exped. Monogr., 39a8: 1-100.

Igarashi, T., 1969. A list of marine decapod crustaceans from Hokkaido, deposited at the Fisheries Museum, Faculty of Fisheries, Hokkaido University, I. Macrura. Cont. Fish. Mus., Fac. Fishe., Hokkaido Univ., 11: 1-15.

Kim, H.S., 1976. A checklist of Macrura (Crustacea, Decapoda) of Korea. Proc. Coll. Natur. Sci., SNU, 1: 131-152.

Kim, H.S., 1977. Macrura. Illustrated Flora and Fauna of Korea, vol. 19. Samwha Publishing Co., Seoul, pp. 1-414. (in Korean)

Kim, J.N. and J.H. Choi, 2006. Two new records of caridean shrimps (Crustacea: Decapoda) from the Korean continental slope of the East Sea. Korean J. Syst. Zool., 22: 51-55.

Kim, H.S. and W. Kim, 1997. Order Decapoda. In The Korean Society of Systematic Zoology, ed., List of Animals in Korea (excluding insects), Academy Publishing Co., Seoul, pp. 212-223.

Kim, H.S. and K.B. Park, 1972. Faunal studies on the macrurans in Korea. R-72-82, Ministry of Science and Technology: 185-222, pls. 1-6.

Kim, W. and S.Y. Moon, 1994. The shrimps (Crustacea: Decapoda) of Ulreung Island, Korea. Korean J. Zool., 37: 262-266.

Komai, T., 1991. Deep-sea decapod crustaceans from the Pacific coast of eastern Hokkaido, northern Japan (Crustacea, Decapoda, Penaeidea and Caridea). Kita-Nihon Teigyobu Kaihou, (24): 55-96

Komai, T., 1994. Taxonomic synopsis of Caridea (Pandalidae, Hippolytidae, Crangonidae) occurring on continental shelf of the Sea of Japan. Cont. Fish. Res. Japan Sea Block, 31: $81-107$.

Komai, T., S. Maruyama and K. Konishi, 1992. A list of decapod crustaceans from Hokkaido, northern Japan. Res. Crust., 21: 189-205.

Miyake, S., K. Sakai and S. Nishikawa, 1962. A fauna-list of the decapod Crustacea from the coasts washed by the Tsushima warm current. Rec. Oceanogr. Wrk. Japan, Spec. Num. 6: 121-131.

Rathbun, M.J., 1902. Description of new decapod crustaceans from the west coast of North America. Proc. US Nat'l Mus., 24: 885-905.

Rathbun, M.J., 1904. Decapod crustaceans of the northwest coast of North America. Harriman Alaska Exped., 10: 1210 .

Sokolov, V.I., 2002. Description of Bythocarides menshutkinae gen. nov., sp. nov. (Decapoda, Hippolytidae). Crustaceana, 75: $137-144$.

Sowerby, J., 1805. The British Miscellany: or coloured figures of new, rare, or little known animal subjects; many not before ascertained to be inhabitants of the British Isles; and chiefly in the possession of the author, i-vi, 1-137, 1-31, 17, 18, pls. 1-76.

Received October 1, 2007 Accepted November 2, 2007 